\title{
Austrian ethics watchdog launched
}

In the wake of the misconduct scandals that have shaken the scientific community in Austria, universities and leading research institutions have created an Agency for Scientific Integrity.

In future, a scientist at any Austrian university or research institute who is concerned about misconduct will be able to turn to this body, the first of its kind in the country, for confidential help. Six scientists from outside Austria will sit on its board, to prevent any influence from the strong local networks that exist in the small country, along
"The research minister said he would create an agency himself if they didn't do it."
Fund (FWF), spearheaded the effort to establish the agency. Plans for such a body had been gestating for a couple of years, he says, but two recent cases have accelerated its birth.

One case involved research from the Medical University of Vienna purporting to show that electromagnetic fields from mobile telephones caused DNA damage. An internal university investigation concluded in August that data in two papers had been fabricated.

That affair came hot on the heels of an even bigger scandal at the Medical University of Innsbruck, which involved with just one Austrian legal adviser. The board members, who will be named in the next few weeks, will determine the organization and procedures of the final agency, which should be operational from early next year.

Christoph Kratky, president of Austria's basicscience funding agency the Austrian Science clinical trials of an experimental procedure for stem-cell therapy to treat urinary incontinence, led by urologist Hannes Strasser. The government Agency for Health and Food Safety later described the trials as illegal and invalid because the researchers had failed to get appropriate approval (Nature 454, 922-923; 2008), and on 6 September The Lancet withdrew Strasser's 2007 paper, which had reported clinical success of the therapy (Nature 455, 150; 2008). The university failed to investigate the affair, and an enquiry by the Austrian National Academy of Sciences is ongoing, although such activity is not within the academy's remit.

The new agency will be useful in cases in which local connections serve to cover up misbehaviour, says Kratky, who is also a structural biologist at the University of Graz. He originally started pushing for an agency because the FWF gets occasional tips about plagiarism from grant reviewers. "We typically convey them to the university involved, but only some investigate properly," he says. At first the universities were sceptical, he says. "But after the Innsbruck and Vienna cases blew up, the research minister Johannes Hahn said that he would create an agency himself if they didn't do it."

Alison Abbott 